\title{
Science and Religion Shift in the First Three Months
} of the Covid-19 Pandemic

Margaret Boone Rappaport

The Human Sentience Project, LLC

400 E. Deer's Rest Place

Tucson, Arizona USA 85704

e-mail:MSBRappaport@aol.com

\section{Christopher Corbally}

Vatican Observatory,

University of Arizona

Tucson, Arizona USA 85721

e-mail: corbally@as.arizona.edu

Riccardo Campa

Institute of Sociology

Jagiellonian University

Grodzka 52 Street

31-044 Cracow, Poland

e-mail: riccardo.campa@uj.edu.pl

\section{Ziba Norman}

University College London

20 Bedford Way,

WC1H 0AL London, England

e-mail: z.norman@ucl.ac.uk 


\begin{abstract}
:
The goal of this pilot study is to investigate expressions of the collective disquiet of people in the first months of Covid-19 pandemic, and to try to understand how they manage covert risk, especially with religion and magic. Four co-authors living in early hot spots of the pandemic speculate on the roles of science, religion, and magic, in the latest global catastrophe. They delve into the consolidation that should be occurring worldwide because of a common, viral enemy, but find little evidence for it. They draw parallels to biblical works, finding evidence of a connection between plague and "social strife." They explore changes in the purviews of science, religion, and magic, and how and why they have changed, as three systems of covert risk management. They speculate on the coming wave of grief when the world populations finally decide that too many people have died, and they envision cultural changes on the other side of the pandemic, to lifestyles, travel, reverse urbanization, and living and working in smaller communities. Using an unusual approach named "crowd-sourced ethnography", they conduct un-traditional ethnography and speculate on management of covert risk in their native countries.
\end{abstract}

Keywords: pandemic, Covid-19, risk, religion, magic, "science and religion", ethnography, culture change, demographic change.

\title{
1. Introduction: The Complex Relationship Between Different Forms of Risk
}

When one of our co-authors asked several local Polish friends to interpret the following man's actions, the consensus they voiced was - double protection.

\section{Crowd-Sourced Pandemic Ethnography 2020}

An unidentified man enters a nameless Polish grocery store. He reaches to the right, applies hand sanitizer, and rubs his hands together. He turns to enter the store and genuflects deeply and crosses himself [24].

The man in the video has made a clear risk decision, and one wonders if his systems for managing health risk have changed. The man appears to reason that two methods of protection are better than one - one, scientific (the hand sanitizer) and the other, religious (crossing himself in a deep genuflection, before entering a grocery market). In these early months of the Covid-19 pandemic, one imagines the man thinking, I've done my part, God, now the rest is up to you.

Another co-author found the religious observance of crossing oneself in a news film of care givers entering a nursing home in Washington State, the first place in the United States to record cases of the novel coronavirus. Filmed from above, one saw a line of men marching, clothed head-to-toe in protective white garments, single file, into the nursing home, to tend to the sick and dying. Two men crossed themselves, as if to say, God protect me. They knew they were entering a high-risk zone. It must have been difficult work, physically and emotionally. 


\subsection{Forms of Risk}

The goal of this pilot study is to investigate expressions of the collective disquiet of people in the first months of 2020, and to try to understand how they manage the covert risk of the pandemic, especially with religion and magic. Thus, the design of the study conforms to an exploratory effort that will hopefully lead to more refined questions and robust study designs in the future.

Between global catastrophic risk that is most inclusive, and risk managed culturally by groups and individuals with rituals meant to be, surely, hopefully, of some benefit, there are other forms of risk. Yet, they can all can be traced to the malaise of people. Something is not quite right, they feel, and they express that feeling in many ways: daily purchasing decisions, routines of family and work, use of transportation or not, voluntary assembly, voting, protests in the street, and violence. All their decisions and the resulting political and economic events come down to the way large numbers of people feel. In the pandemic, they ask themselves: What kind of risk am I taking? How much risk am I taking? Is my family safe?

There is a contagion operating today that goes far beyond the disease caused by the Covid-19 virus. It is an international contagion of sentiment among millions of people, transmitted daily on the internet and television, in newspapers, social media, and in whispers between neighbors. The connections between global catastrophic risk and the discomfiture of people are complex and rapidly changing, especially in a pandemic when communication modalities are also changing fast. Now, we Zoom to discussions of assaying sewage water to detect Covid-19 viruses. It is, after all, an extremely sensitive measure.

Global catastrophic risk comes in two forms for humans: destruction of the environment and destruction of the species. The environment can be destroyed with a meteor hit, nuclear war, or destructive weather. The human species can be destroyed in response to environmental catastrophes, but primarily by other plants and animals, especially some viruses, bacteria, and molds. Pestilence, as documented in the Bible, was sometimes caused by swarms of insects and destruction of human food supplies. Pestilence and plague in the Bible are often associated with civil strife, and they are now, as well. Destruction of human food chains remains quite possible in the present pandemic. While we defend ourselves against an unseen enemy, Covid-19, we remember to defend the insects that maintain our food supplies, like the pollinators.

Types of risk include additional forms of threat that cross national boundaries, like business risk, calculated carefully for clients that need to know whether to invest in business in specific countries. A related form of risk is socio-political, which is also assessed as a service for companies who insure top managers in unstable countries, primarily against kidnapping. Socio-political risk is the daily work of foreign ministers worldwide. It can involve health risk, too, because poor populations are pushed into marginal areas and this can result in further impoverishment and instability, as well as the consumption of non-domesticated species. This mechanism is the basis for the original theory about the origin of the Covid-19 pandemic, and also how Ebola outbreaks now recur. Researchers proposed the theory that HIV came from the eating of bush meat held in a reservoir species of bat, although now it is proposed that HIV has been part of the human experience for thousands of years [27]. Our understanding of Covid-19 may evolve similarly, over long periods of time. The risk may have been with humans for quite some time.

Finally, there are specific forms of risk that have been analyzed so extensively that they now have their own evaluation methodologies, especially three forms: (1) pharmaceutical risk, whose analysis balances benefits of a drug with the risk of side effects, often in relation to cost, (2) environmental risk, whose own approach is most often reflected in environmental impact statements 
(EIS), and (3) workplace risk, or risk to the welfare of employees, contractors, and visitors, which is of great interest to unions and insurance companies.

\subsection{Covert Risk Abatement and Overt Clues to It}

The missing piece in understanding all these forms of risk - from global catastrophic risk to business and pharmaceutical risk - is a deeper understanding of covert risk, i.e., the human perception of risk, how it feels, how humans conceive of it, how they explain why there is a risk now, and who is at fault for causing the risk. From the perspective of most modern religions, the question of fault points to a different frame of reference that connects sickness and punishment imposed by cosmological forces beyond human control. Modern western religions have largely disentangled sickness and sin, or epidemic and retribution. Jesus did so for Christianity, as we read in the New Testament (Mark 2:5-12; John 9:1-3). In the modern age, the question of who or what is at fault for illness or epidemic vaguely hints at religion's predecessor and competitor, magic, which is associated more often with pre-modern societies (although it is retained in modern societies to an extent and in a more covert form). While magic typically assigns fault in order for a remedy to be forthcoming, that type of association is usually not found in religions typical of modern societies. The same logic is present among some Christian believers who interpret the Covid-19 pandemic as a sign from God that humans are not behaving well [21].

Individual cultures help people understand which risks to fear and how much to fear them [6]. Mary Douglas describes this as a selection process (from all the possible threats) and she is largely correct. However, in the case of the current global pandemic, there is no choice because the options have narrowed down to one, the Covid-19 pathogen. Once the risk is identified without doubt, what does one do? The selection process moves on to remediation: what to do about the risk, how much to do, whether to ignore it and the peril if we do. In most instances of contagion, like yearly influenza, we rest assured in the efficacy of a vaccine or the strength of our own immune systems, as well as support from family and friends, and we go on. We are told by scientific experts that the virus causing the Covid-19 pandemic is novel, meaning new, unconventional, uncommon, even strange. The word has accentuated the massive global anxiety about the novel coronavirus. The name implies that the usual remedies may be unavailable or inadequate.

In the current pandemic, a good clue to the nature of covert risk is the explanation that people devise for it, often anthropomorphizing the danger, its source, and its mollification, so that it appears as a struggle between different types of people, demons, spirits, and/or natural forces like the sun, moon, storms, and wind. At first, this appears pre-modern, but it is very common among people living in industrial societies. Yet, it is only rarely openly discussed.

It is not surprising that the explanation for a pandemic at the level of global catastrophic risk is the creation of a new cosmological interpretation, which is conceived when people are under great stress and there is a poorly understood threat of death. People ask themselves, their family, and neighbors how this danger works, what causes it and what can forestall it or appease it, as if it were an angry god. The explanation is a theory about factors operating in a system, and it is not always scientific. Yet, its neuroscience is available for all to read in theories about the left-brain interpreter [10] and the standard decision-making model [11]. Knowing the neuroscience, one would be surprised if humans did not attempt to construct theories that allow them to manage risk with the help of science, religion, and anything else available.

Religion and magic are different risk management systems often used to manage covert risk. However, magic is more deliberate, more manipulative and unvarnished in its motivation to accomplish good or evil ends. The Covid-19 pandemic is so stressful, magic has been openly pressed 
into service. Religion usually supports benign causes, although its actions can be violent and punitive as we read in the New Testament's Book of Revelation. The end of times is preceded by plague, pestilence, and social strife. There is a warning in its fury: Behave well, as if the end of the world is near (1 Thess. 5:16-18), [19]. In this pandemic, religion and magic function at the same time, alongside science, a third, covert risk management system. The three systems of cause and effect are neurologically and cognitively - all rational, logical, and point toward solutions. They derive from the same human efforts to explain cause and effect. When humans under great stress are pressed to create theory (much like Einstein created theory about time and space), they use one, two, or all three systems of explanation. The creative capacity of humans is the same, and in fear of their lives, they will use any theoretical approach.

Theorizing is not just a personal endeavor, but a collective exercise, an innovative group skill that humans have had since the species arose, and some of its foundations evolved long before [22], [23]. The only difference now is that the internet has allowed millions of people to be involved in developing theories, including conspiracy theories, which are rampant in this pandemic. Nevertheless, these three systems of covert risk management - science, religion, and magic - put the same human brain to work in creative, problem-solving, and reassuring ways. Besides, from different frames of reference, they all work. Belief in a cure is part of the cure, and any modern physician will confirm that.

\section{Crowd-Sourced Pandemic Ethnography 2020}

Under the heading, Riti Magici, or Magical Rites, Israel Felipe posted a video on Facebook on May 5, 2020, which appears to be taken with a cell phone. He writes: "Unexpectedly, an Italian witch dances in the square in Salento in a ritual to combat the plague. Pizzic dance of the magical Taranta tradition, very old. I thought it was as beautiful as the image of the pope walking in Rome" (Trans. Portuguese to English [7]). On youtube.com an identical video of the dancer was posted by Jorge Vásquez [25], with these words: ...It is a very old dance. It was originally made in honor of the god Dionysus associated with Bacchus. God of wine and fertility. But later he took other courses and led to a dance that was induced to those who were stung by some spider (tarantula) hence the name taranta-tarantella .... so it is a kind of exorcization of the disease...

Indeed, we co-authors were all mesmerized by this winsome modern witch dancing rhythmically in black to ward off the plague, alone in an Italian plaza. It suggests that the fear and anxiety about Covid-19 was sufficiently high that magic was uncloaked and came out into the center of the city in daylight. As the video begins with the dancer in the distance, the small figure appeared to be not a witch, but, strangely, a nun! The witch's garments looked much like a nun's habit. The black dress looked like the nun's black tunic, with a white collar reminding one of a nun's white wimple.

Finally, we note that this winsome witch in the Italian plaza suggests the same lesson as the Polish grocery shopper at the beginning of this paper: When in doubt, use all risk management strategies available. Two are better than one, and with three, you just might survive.

\subsection{Method: Crowd-Sourced International Ethnography}

The goal of this pilot study is to investigate expressions of the collective disquiet of people in the first months of 2020, and to try to understand how they manage the covert risk of the pandemic, especially with religion and magic. Because the prevalence of the Covid-19 contagion was substantial at the time 
that we four co-authors began our research around March 27, 2020, travel was unwise and we were all in some type of lockdown, in England, the United States, and Poland (with family ties to Italy, an early virus hot spot). In March and much of April, we rarely went out of our homes and those of us who taught or worked at universities, did so remotely via internet.

The four co-authors decided to focus on themes related to religion that our collective knowledge base suggested. It combined the theoretical and applied knowledge and experience of one sociologist, one anthropologist, one international relations expert, and one Catholic priest with an academic background in philosophy, theology, and astronomy. Together we had a wide range of professional experience in the societies of England, the United States, Italy, and Poland. In part, our choice of themes conformed to our own interests, but in part, it was guided by the disciplines we had mastered. Our choices were also guided by the media headlines in late March to late May of 2020, i.e., the first two months of the pandemic, if that is measured by open public acknowledgment of it (rather than early suspicions of scattered cases of an unusual type of pneumonia). We settled upon these four themes, and there are implied hypotheses in each one, which became useful in this pilot study primarily in pointing to future research questions:

(1) The grand unification of problem. The social sciences and political experience of the coauthors together suggested that a common "enemy" (in this case a viral pandemic) should cause widely diverse and dispersed people to draw together in common cause against a common risk. Did we find evidence of this?

(2) Anxiety would be expressed in changes in religious ritual, thinking, and feeling.

We all have written on religious topics previously, and we have amongst the co-authors an ordained pastor. We felt sure we would find changes in religion with heightened anxiety in response to Covid-19 risk. Was this born out? How? Were there any unexpected, out-range changes?

(3) There will be a wave of grief that begins at some point during the pandemic. This expectation was based largely on the HIV/AIDS epidemic, when some of us recall an explosion of grief when so many had died.

(4) People who are isolated by the pandemic will somehow express their desire to re-join their faith communities. What will those expressions be?

After choosing themes that appeared broadly relevant to religious responses to Covid-19 in several western hot spots according to our early observations, we chose a crowd-sourced ethnographic approach and obtained information indirectly from relevant postings of people on the Internet. We did not select an approach for our pilot study that required random sampling, and while bias was undoubtedly introduced, it is, in the end, not relevant to the purpose of the study: hypothesis generation. They were not selected randomly as respondents, but they provided the type of information we sought. Make no mistake: This is not traditional, long-term, in-person ethnography, but it did produce a variety of videos from youtube.com and Facebook, stories from social media, online newspapers, television, and historical documents, poems, cartoons, articles and hypotheses that addressed our four themes, above. We added to this our own personal observations and experiences, and when assembled, this information allowed us to draw some conclusions before restrictions began easing in England, Italy, Poland, and the United States. It is important to note that all this information was collected before the Black Lives Matter protests began worldwide in response to police actions, on May 25, 2020. There is another analysis that would naturally follow this one, which would include the effects of those mass protests on the pandemic (cf. [16]). We shall connect these protests to Biblical 
material from two thousand years ago, which links pandemic and civil disturbance. Plague and civil disruption have apparently gone hand in hand for a very long time.

We are not the only ones to use internet-based methodologies to understand social, political, and economic change. We shall try to make reasonable projections based on our chosen fields of social science (one anthropologist and one sociologist), a priest who is also an astronomer with degrees in philosophy and theology, and an expert in international relations. We are two men, two women, two married, two single. We include an Italian living in Poland, two Americans but one living in London, and one British national who is living in America but whose family remains in Britain. Our observation platforms are diverse, international, and ecumenical. We include an ordained Catholic priest, another Catholic, a co-author raised in the Bahá'í faith, and a Protestant (Presbyterian).

We understand the methodological weaknesses of this unusual approach. Traditional ethnography would involve long in-person interviews of individuals willing to be very responsive. It is a traditional part of participant observation, in which it takes months to gain the trust of respondents in the field. Our field was the developed world, especially early hot spots for the Covid-19 pandemic.

There were advantages to our methodology. It allowed us to sample widely and view behavior that was spontaneous and thought-provoking, as people tend to be in unplanned events, poetry, cartoons, and good writing on current events. Covert risk lies just beneath the surface of people's outward façades. It can be a desperate mental manipulation of what one can do and cannot do to stave off danger. It can be embarrassing. Covert risk exists in summary form in the hearts and minds of people in danger of death. It is the sum total of all the calculations that people make in deciding how they should face danger. Personal risk assessment is a calculation, sometimes mathematical, sometimes based on enormous amounts of research, and at other times, simply a gut feeling. Having assessed the danger and methods to forestall it, people then make decisions about what to do. This makes some types of overt behavior excellent clues to changes in basic human beliefs. We found examples of hope, sadness, anxiety, and humor that revealed covert risk in the early stages of the Covid-19 pandemic. Some of it was clearly a calculation of two (or more) of our personal risk assessment systems: science, religion, and magic.

When an airborne, respiratory viral pandemic is experienced daily on an intimate level, it is easy to forget that the infection of many millions of people is possible. It is a staggering realization, and most of us look away and return to our daily lives of shopping, self-protection, and weighing the desires for a social life with our future existence. In repetitive routines, the crisis becomes trivialized and we forget exactly what is at stake and how much risk is being borne by so many. That insouciance allowed some of the behavior we see in the videos referenced here.

\section{The Grand Unification of Problem}

The two issues we shall first address are the human perceptions of scope and time: scope of the problem, and the pandemic's sense of urgency. We have some clues about scope from the word pandemic itself, implying the global spread of contagion. However, scope is not simply geographic. It involves a feeling, a conviction that everyone on Earth is confronting a common danger, and that all humans are in the fight together. That joint identification should draw people together, but as we have seen in the first months of the Covid-19 pandemic, mortality rates differ by age, sex, race, location, and culture. Sadly, fingers are being pointed to assign fault and create division. Scapegoating is rampant, but then, it was the same in the Middle Ages, in response to the Black Death [4].

Religion, too, has the goal drawing humans together into a community, and we see admirable examples of religion continuing to function well. However, some of the religion that has arisen is not altogether benign and may not be exactly religion. 


\subsection{Mind Map Suggests a Broad Scope}

There is a global consolidation occurring, and it was beginning before the pandemic struck. Still, divisive forces gnaw at unity and try to show it is not true. In the first months of the 2019-2021 viral pandemic, we are all coming under the same grim umbrella defined by the risk of contagion of Covid19. We shall be a younger world population when it is done with us, because the mortality rates are so much higher for the elderly, but we shall be different, too. The question is, how different?

Our attention was drawn to an online diagram from the World Economic Forum's Strategic Intelligence program, based on responses from its Global Forum Expert Network. We examined results on Global Governance in the form of a mind map fashioned from statistical research on relationships among many topics, such as these: countries such as Brazil, China, India, and Turkey; technological advancements like artificial intelligence, robotics, and cybersecurity, and 5G networks; governmental functions like taxation and international security; and international functions like financial and monetary systems, geo-economics, the environment, and natural resource security.

According to WEF's Expert Network, Covid-19 has some interesting close relationships among five intermediate factors: Rising Multipolarity, Anti-Globalism, Transnational Actors, Institutional Pluralism, and Deepening Interdependence. Covid-19 is diagramed closest to the last one, Deepening Interdependence [26]. Unsurprisingly, Covid-19 is connected to deeper interdependence of international players in terms of both spread of the contagion via long-haul air flights, and obtaining resources such as supplies, vaccines, and ventilators internationally. In the geo-political realm, we have seen tensions rise between some major world powers since the advent of the pandemic, while they assign blame to each other. In the economic realm, we have seen tourism and international academic and business meetings grind to a near halt, along with air travel and the hotel industry.

The results on the mind map give us confidence that Covid-19 is related to worldwide changes that go beyond the health threat, itself. Change is occurring everywhere in response to global catastrophic risk. Still, beneath all the figures on dollars, deaths, and soldiers, how are people managing the fear of a lonely death when family cannot visit, and for some, lost wages and housing? As a risk manager and mitigator, how is religion changing?

\subsection{Is Public Health the New Religion?}

On May 21, 2020, an article linking the viral contagion to a kind of religion was published in a daily newspaper from Italy, where the pandemic saw early and high prevalence. Since that time, higher rates have been recorded elsewhere, but the pandemic in Italy starkly revealed the tragedy of lives lost, families separated, and the exhaustion of health care staff without adequate protection or equipment. The headline in Il Foglio translates as, "The pandemic is likely to become the modern version of universal religion; We are in the presence of a secularized messianism" [1]. This is an understandable reaction to a necessarily strong public health outreach program and stringent rules for a culture that appreciates its Italian café society. Public health exhortations can feel like stiff strictures and fingerpointing. The author of the article looks deeper, beneath the obvious, and claims,

Our society is critical of religion. Nonetheless, new and more senseless forms of religiosity are hidden in it, which end up taking on the features of a superstition. We find ourselves in the presence of secularized messianism: instead of waiting for Jesus to return, we wait with passionate hope for the messiah, or the vaccination against Covid-19, which no one can say for sure when and if it will ever come [1]. 
The author mixes magic (superstition) and religion, but his point about waiting is well taken. Waiting for a vaccine is hard.

It would be only a matter of degree to separate public health procedures like cleansing the hands from religious rituals like washing feet, and then separate religious ritual from superstition and magic. How can we know exactly what precautions are needed to face an invisible enemy? This quandary causes people to over-react or under-react, or both. How can one run away from an unseen virus when the entire globe is affected? In the absence of answers, humans invent them in the form of repetitive cleaning routines, purification rituals, and talismans. The aggressive quality of the public health effort sometimes makes people want to relinquish all steps at prevention, go to the beach, and join their friends at the café on the piazza. It is such a difficult choice it becomes a non-choice. Angrily, some say: The virus does not care, why should we?

\subsection{What's Old Is New Again: The Bible on Plague and Social Strife}

Both Old and New Testaments of the Bible help us understand that our own pandemic of 2019-2021 is not the first or the worst. There is a long history of human pandemics in the Middle East and Europe, while large swaths of land were urbanized and populations became dense, while trading and disease vectors were established, and international travel became more widespread. In these pandemics, there tends to be a connection between contagion and social strife.

A new threat is described in the book of Revelation - the end of times. It is foretold by pestilence and plague, and the fear that attends them is due in part to social disruption, which also foretells the end of times. In a parallel way, environmental destruction, marginalization, poverty, and pandemic form a new system in modern, international political thought, just as fearsome as in the Bible. Plagues in ancient and modern society have viral, social, political, and economic similarities. Greek images related to plague, pestilence, and sickness appear in the earliest, Greek-language Bible that survives to modern times [2]. The motifs are strong and ferocious. We read of blood on horses' bridles, social strife, and hardship, which spill over into moral disability.

Plague and pestilence take on cosmological implications in the book of Revelation. We hold that these connotations of hardship survive in the words we use today. Early Biblical images of violence, death, and the end of the world are still carried beneath the obvious meanings of "pandemic" [19]. It makes sense that social reactions are strong and sometimes violent, and cultural reactions to a pandemic are deeply felt and vividly expressed. It also makes good sense to search for the causes of undefined fear in pandemic and the systems of risk management that provide remediation. Changes will likely be expressed in religious thought and behavior. One of religion's main roles is to relieve fear and anxiety, soothe those who mourn, and provide reassurance through parables, ceremonies, and community life. Many of those have already changed with the requirements of social distancing and restrictions on religious gatherings.

The new element of time was introduced in the New Testament. Early Christians were warned that the end of times would not be immediate, so they should curb their sense of urgency. In Thess. 5:16-17, Paul writes: "Rejoice evermore. Pray without ceasing." Our attention was drawn to the phrase, "Pray without ceasing," which denotes both urgency and steadfastness. Is the Covid-19 pandemic reminding us that the end of world may be near? Are pandemic infection and social disruption related? Why are we praying with urgency when it appears that all we do is wait? The conflict can be maddening. Domestic abuse and substance abuse are both up. ${ }^{1}$

Social disruption and pandemic were perhaps not clearly connected at the start of the pandemic lockdowns in March 2020. After the Black Lives Matter (BLM) movement began following police brutalities, they now clearly are. Marching, chanting, singing in closely packed public demonstrations 
has provided the perfect circumstances for additional Covid-19 outbreaks. We wonder which comes first, the pandemic or the social strife mentioned in the Bible. We read that the BLM movement was primed by years of pressure and preparation [3]. Therefore, did the stress of the pandemic ignite the demonstrations? Did the demonstrations exacerbate the pandemic? Or both? Looking back over biblical and historical examples of plague, it seems likely it was both. It was not a random occurrence.

\subsection{Science, Religion, and Politics Rearrange Themselves}

People turn to religion in the present pandemic, but some find little reassurance. The stability built into human religion begins to crumble and many people turn away from it, as one co-author observed in Italy. These same people can lose faith in science, which fails to provide an immediate cure or vaccine, and they are interested most in politics, according to our co-author. Indeed, all modern industrialized societies have substantial proportions who have turned away from traditional faiths. On the other hand, large proportions of believers remain.

In the 2019-2021 pandemic, even politics fails to organize a broad and early testing plan. At this writing, several months into the pandemic, people find themselves chastised by scientific experts to be patient - just as early Christians were chastised by writers of the New Testament to wait for the second coming of Jesus. Is the analogy apt? Probably yes, and probably no. It is complicated. Our view is that the current pandemic, while stirring anxiety and focusing it upon an unknown future, and at the same time, relying on a new scientific manager of risk (a drug, vaccine, and a testing plan), the original anticipatory urgency of early Christians is stirred again and takes on a new form. It is a different millennium, but there is a similar anxiety, in both cases connected to pandemic, plague, or pestilence.

We sense religious and scientific cosmologies shifting. The balance between science and religion strains. People can look for reassurance in both and find little. Science and religion begin to blend, their differences dissolve, their edges blur, and concoctions like the following, darkly humorous reworking of Psalm 23 by cartoonist David Fitzsimmons is published in our media [8]. Its focus is Dr. Anthony Fauci of the US National Institutes of Health. He has provided reassuring leadership in these uncertain times and he has become something of a folk hero, even a savior of sorts. In the beginning and ending excerpts from Fitzsimmons' cartoon that follow, one can see an unusual version of Psalm 23. In the cartoon's image, Dr. Fauci is pictured in a white lab coat, perched on a golden globe that reads, Science, with lit candles in red, white, and blue surrounding him, and a halo adorning his head. In a global pandemic, the values of science blend into religion, and the values of religion trickle over into science.

\section{Crowd-Sourced Pandemic Ethnography 2020}

Dr. Fauci is my shepherd;

I shall not want quackery.

He reassureth my soul:

He leadeth us in the path of scientific

reason for our species' sake...

... Surely goodness and mercy shall follow

Us all our lives at a distance of 6 feet.

And we shall not dwell in this house

Forever.

Amen 


\section{Religion Remains Strong but Changes}

In a once-a-century pandemic, it makes sense to look for change. Our initial impression from crowdsourced media is that there is a massive, collective rise in anxiety due to the Covid-19 virus. The change is substantial, so we hypothesize with some conviction that there is sufficient fear and anxiety to drive social and cultural transformations. We expect some of the change to involve religion because of its traditional role in the management of risk. We do not label this rise in anxiety a psychiatric disorder, although the effects could well be disabling for some people. We point to a malaise widespread upon the land that can distract us and keep us from sleeping or concentrating on our work. One of the co-authors has begun, with a chuckle, to use the phrase, "Coronavirus Derangement Syndrome" 2 when a new and unidentified malady crops up while on lockdown. No one wants to visit a doctor's office or hospital now, because of the fear of contagion, so we treat our family's small illnesses ourselves. Home-based medicine has emerged again, where it started. The availability of telemedicine appointments has especially helped the high risk and elderly.

Just as science and religion are re-aligning themselves and jostling for position in these times of stress, so too are religion and magic. In our distributed, crowd-sourced methodology that is anythingbut-traditional participant observation, we have succeeded in uncovering hints of social and cultural trends beginning to occur in these first months of the 2019-2021 pandemic. We still do not know how much fear is appropriate for this virus, so we live tentatively, holding our breaths, anxiously awaiting a cure or vaccine. We co-authors search for signs of change in religion and for a sign the pandemonium is winding down and a new normal is stabilizing with innovations like temperaturechecking drones, immunity passports, and "no cash" [17].

\subsection{The Forces of Wrath and Mercy Remain Stable, but Updated}

The double-edged sword of divine wrath and mercy is a very old concept in the Circum-Mediterranean region that goes back more than two thousand years. It forms an important part of the doctrine of divine retribution in all the major world religions that developed in the region. We see clearly from recent survey results that this concept is not just a remnant of the past, but clearly retained in the 20192021 pandemic. An AP-NORC poll in conjunction with the University of Chicago Divinity School finds that respondents are looking for a deeper meaning in the Covid-19 pandemic. Among Americans who believe in God, 31 percent feel strongly that the virus is a sign that God is telling humanity to change. Forty-three percent of Evangelical Protestants believe this strongly [21]. The four co-authors agree that there is a sizable proportion of individuals in the modern societies of England, the United States, Italy, and Poland who see the pandemic as a sign from God for humans to behave differently.

At the same time, most modern Christian faiths, including Catholicism, have disentangled God's direct retribution in the form of natural events. No longer is an earthquake, for example, seen as punishment of people for their sins. Instead, the modern Catholic Church prays for victims of an earthquake (cf. [12]). Still, one hears the viewpoint voiced among people of many Christian faiths that the Covid-19 pandemic is punishment for human ills. The co-authors' view is that it is a re-working of an old theme and an expression of great fear in the face of a new, unknown contagion. In times of stress, people often re-work traditional cultural motifs in the face of new and daunting problems. The result is a blend of old and new in expressions cultural creativity, perhaps like the following. 


\subsection{Modern Talismans Are Pressed into Service, and Converted to Religion}

There is a wide range of religious and quasi-religious objects that offer support in the face of stress and anxiety. It is said that they help people focus, or pray, or remind them of special people or times in their lives. Some of them are simply good luck charms, a physical object that is perhaps linked to a more spiritual realm. Beliefs in talismans, amulets, and charms are widespread, and they span premodern and modern religions. Some are not associated with any religious belief, which was initially the case for the talisman described in this conversation between two of the co-authors. The talisman surely illustrates a type of antidote to the anxiety about the coronavirus. However, the most interesting aspect of the conversation is that these two co-authors together create something different with the talisman. That creation signals the perpetuation of religious and community affiliations with people, even in isolation from them.

\section{Crowd-Sourced Pandemic Ethnography 2020}

\section{Co-Author A:}

After the pandemic struck, I stopped shopping. I was convinced it was a waste of time because if I got the virus, I'd never survive, not with asthma. I was high-risk... But, that changed at some point and I guess I decided I was going to live. So, I made a purchase... It was a green amethyst ring that I have named my 'Coronavirus Ring,' after I noticed that the $18 \mathrm{~K}$ gold stations on either side of the stone look a little like the 'corona' of the virus. I thought to myself (having become just a tad more OCD and a tad more mystical as this thing goes on), 'No, I can't encourage this virus!' And then, I noticed that the large green amethyst stone (which goes nicely with my gold wedding band, the plain one, it's not a time for diamonds), was actually separating - splitting - defeating this virus! I said to myself that if I survive this thing, I will give the green amethyst set to my cousin, who just moved in to self-isolate with her beau. I thought she would like it, even if I died.

\section{Co-Author B:}

Thank you for sharing this with me. Now, let's imagine the coronavirus amethyst ring is an amulet to ward off this demon. Imagining the moment when you give your cousin this ring, a moment of triumph, is a powerful image to carry through these days, focusing the mind in this way doesn't seem at all odd to me.

In this example, a non-religious talisman first obtained largely in innocence became a good luck charm. Then, it is converted into a symbol of religious community and a meaningful relationship between people - even people who are socially distanced to prevent spread of the virus.

\subsection{Believers Strain to Re-Join Their Religious Communities}

Social distancing must eventually accommodate deeply held religious concepts about how to worship, how to behave toward friends and family, and how to die. In widely published sources, we see the traditions of established religions accommodating, for example, in an image of a worshiper in Liverpool, England, sitting alone facing the altar of an Anglican church and preparing to celebrate Holy Communion remotely with the priest on his laptop screen [17]. A Facebook post shows a New York priest baptizing an infant with a water pistol while the mother holds the baby up, looking very 
pleased. Are these examples a sacrilege? Jokes? "No" to both. It is the way that culture usually changes, slowly and carefully, but not quite so slowly or carefully in a pandemic. Social change speeds up as the sense of urgency is widely, deeply felt.

An example of a brush with death by Monsignor Derio Olivero, Bishop of Pinerolo, gives an intimate reflection of the longing for community in a time of social distancing, absence of regular religious services, and an inability to see family [20]. Indeed, the Monsignor's harrowing account of an extraordinary mystical experience recalls St. Ignatius of Loyola's "movement of faith in illness," i.e., personal discovery while recovering from illness.

\section{Crowd-Sourced Pandemic Ethnography 2020}

Vatican City, April 27, 2020 [excerpts from an interview with Monsignor Derio Olivero, 59, bishop of Pinerolo]

The Monsignor: You need caution: I risked dying from that virus... I suggest prudence to the bishops. You don't know fully what this disease is...

Question: How do you comment on the clash between bishops and government?

Answer: ...This is not the time to show your teeth but to collaborate... Those who show their teeth reaffirm their rights and seem to win, but they will collaborate in defeat.

Question: How was your illness?

Answer: Very hard... At a certain point I was sure I would die. The doctors also confirmed it to me. Before the illness, if they asked me what I thought of death I would have I replied that I was very afraid. And instead, in those moments when I was really close to death I was at peace, calm.

Question: How did you feel?

Answer: I felt there was a force that kept me alive. I didn't have the strength to move, but I felt a presence that kept me up. When I woke up, I saw that hundreds of people gathered to pray for me.

Question: What were your feelings exactly?

Answer: As if everything was evaporating, all things, all roles, all. Do you know what was left? Trust in God and relationships built. Here I was only made of these two things. They were two solid things, they were me...

This disease affects the breath. In the Bible breath means spirit, life. The spirit that is given. Every breath is a gift to be tasted, it comes from God.

Monsignor Olivero's feeling of a presence and his awareness of others gathering in prayer, reflects a yearning of oneness with his faith community. When social distancing prevails and lockdown follows - not to mention, hospitalization! - people feel isolated and seek in different ways to re-join their communities. Perhaps this is one source of the sense of urgency felt in a pandemic: The sense of grief at losing that community and wishing to rejoin those who are temporarily lost. 
In a different context, England rather than Italy, one of our co-authors reports the same strain toward joining a faith community. The co-author imagines that the walkers outside her window can hear the prayers inside, forming a community where none really existed. Or did it?

\section{Crowd-Sourced Pandemic Ethnography 2020}

Thank you for your Easter Greetings. We had our own private vigil and today celebrated with our Church on Zoom. The quiet of these days has made it far easier to connect with the Paschal mystery. Yesterday was like high summer in London, a balmy breeze, not dissimilar to a warm spring evening in the Holy Land. We read scriptures aloud with windows wide open, wondering if it might touch, ever so slightly, the ears of those passing. Those who walk these days are, as a rule, never going anywhere, they are just walking, so perhaps more open to the experience of what is happening in the background.

\section{Conclusion: The Coming Wave of Grief and the Cultural Changes to Follow}

Those of us old enough to recall the HIV/AIDS epidemic as adults in the 1980s may remember being surprised by the mention of grief. At some point (currently undefinable for the Covid-19 pandemic), there will come a sense that too many people have died in too short a time, and grieving must commence. It will be as if a conscious population decides to turn some imaginary corner and go on. At this writing, in June 2020, there is no such sense that grieving has begun or that it should. It is surely a time for grieving individual people. Whole families feel the brunt of grief. The broader sense of a time to grieve will be much like 9/11, when the twin towers in New York City were hit and destroyed, and many died. "We've been hit," will be the voiced conclusion. Now, it is as if the world population is still holding its collective breath, waiting to see just how bad the pandemic will hit South America, India, and Africa, while they worry about second and third waves in the northern hemisphere.

The question remains: When will the broad-based grieving begin, and what will determine that collective decision? We read of expectations of this grief among the self-aware, along with the specter of future post-traumatic stress disorder. US Governor Andrew Cuomo states that the "coronavirus will leave an 'entire generation' facing PTSD as he opens up on 'heavy burden' of death toll and reveals 'I still hold myself responsible"' [9]. Just how much survivor guilt will there be? Unknown, but, at the same time, many of us have run into difficulty concentrating. A New York Times editorial asks, "Trouble Focusing? Not Sleeping? You May Be Grieving" [15]. Many of us have run into problems concentrating, even without knowing anyone who has died (yet). This suggests that it is not just the death of people that will be mourned, but a way of life, as well. We will not enjoy, at least for some time, the same easy way of sipping a glass of wine in a steamy, packed bistro, or enjoying our friends, elbow-to-elbow in a rathskeller. "Those were the times!" we will say repeatedly and grieve. We will never enjoy an international flight again in quite the same way.

Things have changed. When we arrive at a new and different lifestyle, after we all receive a vaccine (we ardently hope), we shall not go back to the same way of living before the pandemic. There is an apt aphorism: "You cannot step in the same river twice." When we step out of this bubble, what will we find? The writers in the literary magazines and hot spot newspapers have begun to speculate. We shall only be able to move freely with some form of "immunity papers" like an "immunity passport" that states we have had the Covid-19 virus and are immune (one presumes, but not with certainty), or that one has had a vaccine. One of the co-authors has name and number stamped on ocular implants after cataract surgery, and so is quite identifiable. Will the same proof of status be common on the other side of the pandemic? Will we socialize in smaller groups? Will we travel less? 
It is very likely that the rapid urbanization of a New York City or London will slow down, and people will "decentralize," living much of their lives in smaller communities, linked to urban life via internet, satellite, and eventually, the once-monthly trip on high-speed commuter rails. Will courtship change? Will grandma move back home from dangerous nursing homes? Will college dormitories downsize? Whatever the changes to come, we four co-authors hope that, in this exploration of changes in religion in response to the Covid-19 pandemic, readers begin to understand a sobering thought: There is continuity and strength in our religious institutions, but we will miss so much about the times before the coronavirus assault on world society, and we will know with certainty we have changed forever.

\section{References}

1. Appel, $\mathrm{K}$. The pandemic is likely to become the modern version of universal religion; We are in the presence of a secularized messianism, Il Foglio, May 21, 2020, at 6:00 a.m. In English and Italian.

2. Bromiley, G. W. Theological Dictionary of the Bible, Abridged in One Volume, From G. Kittel, G. Friedrich, and G. Bromiley (eds.), Grand Rapids, Michigan: Eerdmans Publishing Company, 1985.

3. Campo-Flores, A., and J. Jamerson. Black Lives Matter's Years of Pressure Paved Way for Sudden Police Overhaul, Wall Street Journal (online), June 18, 2020, 5:40 pm ET. https://www.wsj.com/articles/black-lives-matters-years-of-pressure-paved-way-for-suddenpoliceoverhaul-11592516422.

4. Cunningham, C. J. The "Black Death Scapegoat Conjunction" of 1345, Mercury 49 (1), 11, 2020.

5. Delingpole, J. Delingpole: Piers Morgan May Have Terminal Coronavirus Derangement Syndrome, The Patriots Report (online), April 29, 2020. https://thepatriotsreport.com/2020/04/29/delingpolepiersmorgan-may-have-terminal-coronavirus-derangement-syndrome/.

6. Douglas, M., and A. Wildavsky. Risk and Culture; An Essay on the Selection of Technological and Environmental Dangers, Berkeley, California: University of California Press, 1983.

7. Felipe, I. Riti Magici [Magical Rites], a video posted on Facebook on May 5, 2020, at 4:20 AM. Coauthor Riccardo Campa re-posted the video on Facebook. It is now available at:

https://www.facebook.com/583133302/posts/10157721309413303/?sfnsn=mo\&d=n\&vh=i.

8. Fitzsimmons, D. Cartoon of Dr Anthony Fauci, Cagle Cartoons, April 30, 2020.

9. Fruen, L. Gov. Andrew Cuomo tells The Daily Show coronavirus will leave an 'entire generation' facing PTSD, The Daily Mail online, Updated April 23, 2020, 04:19 EDT.

https:/www.dailymail.co.uk/news/article-8247793/Gov-Andrew-Cuomo-says-coronavirusleaveentire-generation-facing-PTSD.html.

10. Gazzaniga, M. S., R. Ivry, and G. Mangun. Cognitive Neuroscience. The Biology of the Mind. Fourth Edition, Cambridge, MA: MIT Press, 2014.

11. Glimcher, P. The Emerging Standard Model of the Human Decision-Making Apparatus, In M. S. Gazzaniga and G. R. Mangun (eds.), The Cognitive Neurosciences, 5th ed., pp. 683-91, Cambridge, MA: MIT Press, 2014.

12. Il Fatto Quotidiano. Radio Maria excommunicated from the Vatican after the words on the earthquake: 'Offensive and scandalous', Nov. 4, 2016. Accessed June 22, 2020.

13. Imgflip.com. A New Study Reveals That Those Afflicted with Trump Derangement Syndrome Are Also More Likely to Contract Coronavirus Derangement Syndrome, Coronavirus Memes \& GIFS, 2020. https://imgflip.com/i/3ugp4x.

14. Knauer, T. J. Coronavirus Derangement Syndrome, Medium online. March 31, 2020. https://medium.com/@TrentKnauer/coronavirus-derangement-syndrome-d43ffd2dd976. 
15. Kwon, R. O. Trouble Focusing? Not Sleeping? You May Be Grieving? New York Times online, April 9, 2020. https://www.nytimes.com/2020/04/09/opinion/sunday/coronavirus-griefmentalhealth.html.

16. Madrigal, A. C., and R. Meyer. America Is Giving Up on the Pandemic; Businesses are reopening. Protests are erupting nationwide. But the virus isn't done with us, The Atlantic online, June 7, 2020. https://www.theatlantic.com/science/archive/2020/06/america-giving-up-on-pandemic/612796/

17. Mayo, J. Body temperature drones, immunity passports, no cash allowed and Brexit postponed: Jonathan Mayo imagines 'the new Normal' one year after Britain emerges from lockdown, Daily Mail online, May 2, 2020. https://www.dailymail.co.uk/news/article-8279061/JONATHANMAYOimagines-new-normal-one-year-Britain-emerges-lockdown.html.

18. Occupy Independents (online). Woke Writers Are Suffering from Coronavirus Derangement Syndrome. Updated March 21, 2020. https://www.occupyindependents.com/woke-writersaresuffering-from-coronavirus-derangement-syndrome/.

19. Rappaport, M. B., C. Corbally, R. Campa, and Z. Norman. Wrath, Mercy, Pestilence, and Plague: How the Wisdom of The Ancients Offers Courage in Pandemic, Orbis Idearum 8(1): 13-27, 2020.

20. Rodari, P. Il vescovo di Pinerolo: "Serve prudenza. Io per quel virus ho rischiato di morire" [The

Bishop of Pinerolo: Caution is needed. I risked to die because of the virus], La Repubblica, April 28, 2020, p. 5.

https://rep.repubblica.it/pwa/intervista/2020/04/27/news/il_vescovo_di_pinerolo_serve_prudenza_io_p er_quel_virus_ho_rischiato_di_morire_-255053340/.

21. Schor, E., and H. Fingerhut. Poll: US Believers See Message of Change from God in Virus, report on a survey sponsored by the University of Chicago Divinity School and the Associated Press-NORC Center for Public Affair Research, Associated Press, May 16, 2020. https://apnews.com/0bed79d024a56d2ac0b93bc51df80e9b.

22. Smaers, J. B., A. H. Turner, A. Gómez-Robles, and C. C. Sherwood,. A Cerebellar Substrate for Cognition Evolved Multiple Times Independently in Mammals, eLife Sciences 7, 2018. DOI 10.7554/e/life.35696.

23. Tanabe, H. C., D. Kubo, K. Hasegawa, T. Kochiyama, and O. Kondo. Cerebellum: Anatomy, Physiology, Function, and Evolution, In E. Bruner, N. Ogihara, and H. C. Tanabe, Digital Endocasts, Replacement of Neanderthals by Modern Humans Series, pp. 275-289, Tokyo, Japan: Springer Japan, 2018.

24. Trunkwalter. K. Video online at youtube.com with over 1,900 Comments, 2020. https:/www.facebook.com/katarzyna.trunkwalter/videos/2670632529885614/?t=0.

25. Vásquez, J. An Italian Witch, video online at youtube.com, 2020.

https://www.youtube.com/watch? $\mathrm{v}=\mathrm{yw} 2 \mathrm{fb} 5 \mathrm{mTcws}$.

26. WEF-World Economic Forum. WEF Strategic Intelligence semantic field on Global Governance, accessed 20 June, 2020. https://intelligence.weforum.org/topics/a1Gb0000000LHN2EAO.

27. Zajac, V. Evolutionary View of the AIDS Process, Journal of International Medical Research 46 (10), 2018, pp. 4032-4038.

\section{Notes}

1. New York physician Dr. Nicole Saphier spoke in a news video to the online news source, Daily Mail, about the effects the coronavirus was having on suicides, self-harm, domestic violence, and drug abuse. She said they were on the rise during the coronavirus pandemic. The news video is available at: https://www.dailymail.co.uk/video/newsalerts/video-2168196/Suicides-drug-abuse-risecoronaviruspandemic.html. 
2. The origin of the expression Coronavirus Derangement Syndrome is apparently widespread (e.g., [5], [14], [13], [18]). It appears to be a derivative of a similar expression used to describe Americans who were unhappy that Trump won office in 2016. They were said to be suffering from Trump Derangement Syndrome. Our co-author's usage was not unique. 